\title{
Control, Participation, and Effectiveness in Four Yugoslav Industrial Organizations
}

\begin{abstract}
This study deals with control, participation, and effectiveness in four Yugoslav industrial organizations. It investigates (1) the relationship between degree of participativeness in workers' councils, and participativeness defined in terms of social-psychological relations among all members of the organization; and (2) the relationship of participativeness to the distribution of control and to criteria of organizational effectiveness. The data were obtained from questionnaire responses of council and other members in four organizations and from a group of expert judges. Tentative conclusions suggest that the workers' council should be viewed as part of a larger system involving the day-to-day interactions of organization members.
\end{abstract}

The Yugoslav industrial organization operates within a framework of workers' selfmanagement. The supreme authority in each organization is the workers' collective, which consists of all members of the organization. The members elect and delegate most of their authority to a workers' council of about 30 members. The council meets approximately once a month and is responsible for deciding the prices of the organization's products, the allocation of net profit, production plans, budgets, and other basic issues. The workers' council has the power to discharge managers. The council also elects a managing board of approximately $10 \mathrm{mem}$ bers which acts as an agent of the council. The managing board meets more frequently than the council and carries out the council's directives on a daily basis.

The Yugoslav system formally includes two main hierarchies in each organization. The first hierarchy, concerned with self-management, extends from the workers' council at one end, with the managing board subordinate to the council, and finally the managers subordinate to the managing board. The second hierarchy is like the conventional chain of command, with managers at one end, followed by heads of economic units (roughly equivalent to department heads), supervisors, and the rank and file workers. In addition, several groups within the orga- nization, such as the party, the trade union, and the youth organization have significant influence.

The system of workers' self-management has been designed to achieve ideological and practical objectives. Ideologically, the system attempts to realize a form of democratic or participative management. Practically, it is designed to minimize or eliminate conflicts, improve interpersonal communication, increase confidence and trust among members, increase their involvement, improve their motivation, and maintain their support for the organization and its objectives (Adizes, 1968; Deleon, 1956; Dunlop, 1959: ch. 8; Kolaja, 1965; Kralj, 1969; Mandić, 1958; Sturmthal, 1964).

Such results are consistent in a general way with a number of theories about participative management, for which some empirical support has been found (Friedmann, 1955; Katz and Kahn, 1966; Likert, 1961, Tannenbaum, 1966). These theories remain controversial, however. Furthermore, the Yugoslav form of participative management differs in significant ways from many of the participative models that have been developed elsewhere and that have been the subject of research. The Yugoslav system is based on social ownership of the organization, and attaches primary importance to the workers' council, an elected and representa- 
tive legislative body. In theory, the council provides the means through which participation is realized and through which the desired effects of participation are achieved. Many behavioral science approaches, however, are concerned more than is the Yugoslav model with social and psychological processes within organizations as, for example, the degree to which influence between persons in a hierarchy is unilateral or mutual, or the way in which communication flows within the organization. The Yugoslav and behavioral science models are not mutually exclusive however, and, in fact, some advocates of one model simply emphasize and make explicit what advocates of the other model consider only implicitly. It therefore seemed appropriate to explore whether $\mathrm{Yu}$ goslav organizations that differed in the participativeness of councils differed also in participativeness as measured in terms of the social-psychological processes within them. We would expect such a correspondence. Also, if research in the U.S. is applicable to Yugoslavia, one could expect that organizations with more participation would be characterized by higher levels of loyalty, involvement, and motivation of members, and by a greater total amount of control than organizations with less participation (Tannenbaum, 1968). Furthermore, if some contemporary, normative theories of organization (for example, Likert 1961) are relevant to organizations in Yugoslavia, these effects of participation should be associated with criteria of organizational effectiveness.

These hypotheses assume that the effects of participation in the council pervade the larger organization; that is, that since all members of the organization participate indirectly, if not directly, the effects of participation are therefore felt by all members. Evidence concerning the effects of indirect participation, however, has not been very strong (Emery and Thorsrud, 1965; Coch and French, 1948; Dahrendorf, 1955; Lammers, 1967). A more conservative expectation is that while the council has effects on the motivation, loyalty, and involvement of council members, these effects are not common to members of the organization as a whole.

This study deals with the relationships between control, participation, and effectiveness. ${ }^{1}$ Data are presented relevant to these relationships, with some comments on the possible role of the workers' council in affecting these relationships. The data, derived from the responses of members of four Yugoslav organizations to a questionnaire and from a group of expert judges in the central trade union organization of Slovenia, are subject to serious limitations, but they are offered for the information they provide where there is still relatively little data available.

\section{METHOD}

To explore the hypotheses, organizations were selected that differed in the participativeness of their councils. Accordingly, two pairs of organizations were chosen, each pair including plants with reasonably comparable technologies and of approximately equal size; but with one plant in each pair judged to have a relatively participative council. The judgments were based on an analysis of the workers' councils' meeting records. The criteria included the proportion of members who took part in the discussion of the council, and the quality of the debate.

Table 1 presents some characteristics of

Table 1. Characteristics of industries

\begin{tabular}{|c|c|c|c|c|}
\hline Industry & Size & $\begin{array}{c}\text { Male } \\
\text { employees } \\
\%\end{array}$ & $\begin{array}{c}8 \text { years } \\
\text { education } \\
\text { or less } \\
\%\end{array}$ & $\begin{array}{c}\text { Age } \\
\text { below } \\
30 \\
\%\end{array}$ \\
\hline Rubber & 1995 & 69 & 50 & 37 \\
\hline Shoes & 1109 & 46 & 49 & 47 \\
\hline $\begin{array}{l}\text { Wood prod- } \\
\text { ucts I }\end{array}$ & 600 & 70 & 55 & 23 \\
\hline $\begin{array}{l}\text { Wood prod- } \\
\text { ucts II }\end{array}$ & 650 & 50 & 62 & 41 \\
\hline
\end{tabular}

the four plants. The rubber plants and wood products I plant had the more participative councils. All of the plants used modern technology and mass production. The wood products II plant was probably the most different, since it had modernized its pro-

1 A. S. Tannenbaum would like to thank the Ford Foundation for a grant to the University of Michigan, which enabled him to participate in this project. 
duction facilities only recently and may have been operating under the handicap of a relatively untrained work force, including a relatively high percentage of young women with little formal education.

All council members $(N=30)$, and a random sample of approximately 120 noncouncil members in each plant were asked to complete written questionnaires. Research assistants were available to help respondents who had difficulty. With the exception of a few questions, the response rate was excellent; therefore, the results presented are based on the responses of most of the 590 organization members divided among four plants.

\section{Questionnaire}

The questionnaire included 38 questions and was developed to measure three major, social-psychological aspects of the industrial organization. One group of questions dealt with control within the organization. Respondents were questioned about how much control should be exercised-that is, ideal control-as well as how much was exercised -that is, actual control-by various groups within the organization. These questions were drawn from questionnaires previously used in the U.S. (Tannenbaum, 1968) and in Yugoslavia (Kavčič, 1968; Rus, 1964; Siber et al., 1966; Zupanov, 1964; Zupanov and Tannenbaum, 1968). A second set of questions included measures designed by Likert (1961) about social-psychological aspects of participation, such as, the extent to which leaders involved members in decision making, the direction and accuracy of communication, and the degree to which leadership, or supervision, was supportive and appeared to encourage confidence and trust. A third set of questions was designed to measure job motivation and involvement of members and their identification with the organization. These questions were adapted from questionnaires developed by Bowers (1969) and by Patchen (1963). Finally, several questions were asked about age, education, party membership, and other characteristics of members.

\section{Measures of Organizational Effectiveness}

Although authors differ in their definitions of effectiveness (Yuchtman and Seashore, 1967), many agree about the operational criteria for this concept. Six criteria listed in rows 1-6 of Table 2, were selected to be measured through the judgments of experts familiar with the organizations. Three of the criteria, productivity, economic success, and wages which, in Yugoslav organizations, reflect profitability, are considered by many authors as criteria of effectiveness in industrial organizations. These criteria indicate something about the organization's ability to maintain itself and to enhance its power in

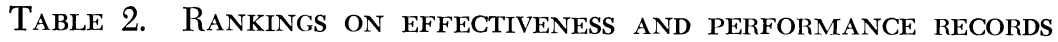

\begin{tabular}{|c|c|c|c|c|c|}
\hline Criteria of effectiveness & $\begin{array}{l}\text { Rank-order } \\
\text { correlation }\end{array}$ & Rubber & Shoes & $\begin{array}{l}\text { Wood } \\
\text { products I }\end{array}$ & $\begin{array}{l}\text { Wood } \\
\text { products II }\end{array}$ \\
\hline & \multicolumn{5}{|c|}{ Rankings } \\
\hline Productivity & 1.00 & 1 & 2 & 3 & 4 \\
\hline Economic success & .95 & 1 & 2 & 3 & 4 \\
\hline Management & .60 & 1 & 2 & 3 & 4 \\
\hline Wages & .95 & 1 & 2 & 4 & 3 \\
\hline Self-management & .80 & 1 & 3 & 2 & 4 \\
\hline Social-psychological relations & .95 & 1 & 4 & 2 & 3 \\
\hline \multirow[t]{2}{*}{ Overall effectiveness } & & 1 & 2 & 3 & 4 \\
\hline & \multicolumn{5}{|c|}{ Performance records } \\
\hline $\begin{array}{l}\text { Net productivity per worker, } \\
1965 \text { (in new dinars) }\end{array}$ & & 29,023 & 21,901 & 17,476 & 14,937 \\
\hline $\begin{array}{l}\text { Average wages per worker } \\
\text { (in new dinars) }\end{array}$ & & 616 & 544 & 526 & 532 \\
\hline Ratio of income to costs & & 1.69 & 1.63 & 1.71 & 1.69 \\
\hline
\end{tabular}


its environment, as do quality of management and quality of social-psychological relations. Finally, because self-management is formally stated as an objective for the Yugoslav organization, the degree to which the plants realized this objective was included as part of an overall measure of effectiveness.

Seventeen officials of the Trade Union Council of the Slovenian Republic were asked to rank the four organizations on the selected criteria. The raters were very familiar with the organizations, and each responded independently of the others and was not informed about the results of the questionnaire, even though the data had been collected before their effectiveness ratings. The following instructions were given:

Our Center for Public Opinion Research is conducting an investigation about self-management in four plants. We now need your help. Please rank these four organizations on the following six items. Assign to the best the number 1 and so on.

Table 2 shows the rank order of the plants for cach of the criteria, based on the averages of the rankings by the 17 judges. Agreement among the judges was measured by correlating the average ratings of 8 randomly selected judges with the average ratings of the remaining 9 . Table 2 gives the resulting rank-order correlation for each criterion. Most of the criteria are measured with reasonable reliability and except perhaps for quality of social-psychological relations in the plant, the criteria relate reasonably well to an overall index of effectiveness based on the average of rankings of all items, indicated in row 7 of Table 2 .

The high degree of agreement among the raters was not surprising, since the raters were familiar with the performance records of the four plants. The records show a ranking of the plants very similar to that given by the 17 judges, as rows 8 to 10 in Table 2 indicate. The ratio of income to costs, however, did not vary much among the four plants, and the rank order of plants on this index did not correspond to the ranking based on other data. This ratio of income to costs is, perhaps, more than the other crite- ria, like an index of efficiency which Katz and Kahn ( 1966) distinguished from effectiveness. The more effective plants achieved higher productivity per capita than the less effective plants and maintained a relatively high level of profitability, although the cost for achieving this favorable level of performance was greater than in the less effective plants.

Although the original selection of organizations was based on a pairing, the plants are ranked here in a single ordering. Since the raters had no difficulty in making such a ranking, one can make comparisons within pairs as well as among all the plants.

\section{RESULTS}

The initial judgments concerning the participativeness of councils in the four plants do not correspond in the expected manner to any of the questionnaire measures nor to the ratings of effectiveness by the 17 experts. The absence of positive findings is of course open to a number of interpretations including that the measures lack validity, but the data are not without meaning.

\section{Council Members and \\ Non-Council Members}

Council members differed significantly from non-council members, and since the differences were essentially the same in all four plants, the data from all plants are combined in Table 3.

Table 3. Comparison of COUNCIL

MEMBERS AND NON-COUNCIL MEMBERS

\begin{tabular}{lcc}
\hline \multicolumn{1}{c}{ Data } & \multicolumn{2}{c}{ Members } \\
\cline { 2 - 3 } & $\begin{array}{c}\text { Non-council } \\
\%\end{array}$ & $\begin{array}{c}\text { Council } \\
\%\end{array}$ \\
\hline Male & 54 & 77 \\
Communist party & 7 & 16 \\
Education 4 years or less & 58 & 38 \\
Under 30 years & 41 & 24 \\
Supervisory or management & 9 & 18 \\
Highly involved, motivated, & & \\
identified ( Question numbers & & \\
here correspond to the question & & \\
numbers in Table 4.) & 44 & 61 \\
$\quad$ Question 3 & & 43 \\
Question 4 & 26 & 69 \\
Question 5 & 36 & 70 \\
\hline
\end{tabular}


Council members were more likely than non-council members to be male, older, more educated, members of the party, and to hold supervisory or managerial positions. They were also more highly involved and motivated in their work than non-council members, as indicated by questions 3,4 , and 5 , and they responded more positively than non-council members to question 7, one of several designed to measure identifi- cation with the enterprise. They did not, however, differ from non-council members in response to other questions, 1-3, 6, 8, and 9 shown in Table 4, about identification with the enterprise and favorable attitudes toward their work situation.

Differences were expected between council and non-council members on the latter questions, consistent with the differences in work motivation and identification shown in

Table 4. Percentage of Respondents high in motivation, involvement, AND IDENTIFICATION

\begin{tabular}{|c|c|c|c|c|c|c|}
\hline \multirow{2}{*}{\multicolumn{2}{|c|}{ Question }} & \multicolumn{5}{|c|}{ Wood products } \\
\hline & & Answer & II & I & Shoes & Rubber \\
\hline \multicolumn{2}{|r|}{$\begin{array}{l}\text { 1. Do you look forward to coming } \\
\text { to work each day? }\end{array}$} & Always & 37.9 & 38.6 & 52.3 & 53.7 \\
\hline \multicolumn{2}{|r|}{$\begin{array}{l}\text { 2. Does your job give you a chance } \\
\text { to develop your abilities? }\end{array}$} & $\begin{array}{l}\text { Somewhat or } \\
\text { very much }\end{array}$ & 26.6 & 45.3 & 46.3 & 49.7 \\
\hline \multicolumn{2}{|r|}{$\begin{array}{l}\text { 3. How often do you try out, on your } \\
\text { own, a better or faster way of } \\
\text { doing something on the job? }\end{array}$} & $\begin{array}{l}\text { Once a week or } \\
\text { more often }\end{array}$ & 40.8 & 52.1 & 44.3 & 51.0 \\
\hline \multicolumn{2}{|r|}{$\begin{array}{l}\text { 4. Do you agree or disagree that in } \\
\text { your kind of job, it is usually } \\
\text { better to let your supervisor worry } \\
\text { about new or better way of doing } \\
\text { something on the job? }\end{array}$} & $\begin{array}{l}\text { Do not agree } \\
\text { strongly }\end{array}$ & 63.5 & 68.1 & 63.8 & 71.4 \\
\hline \multicolumn{2}{|r|}{$\begin{array}{l}\text { 5. How many times in the past year } \\
\text { have you suggested to your super- } \\
\text { visor a different or better way of } \\
\text { doing something on the job? }\end{array}$} & $\begin{array}{l}\text { About } 3 \text { times } \\
\text { or more }\end{array}$ & 40.0 & 50.7 & 35.6 & 47.6 \\
\hline \multicolumn{7}{|c|}{$\begin{array}{l}\text { 6. If you could begin working over } \\
\text { again but in the same occupa- } \\
\text { tion as you are in now, how }\end{array}$} \\
\hline \multicolumn{2}{|r|}{$\begin{array}{l}\text { 7. How do you feel when you hear } \\
\text { or read about someone criticizing } \\
\text { your enterprise, or your enterprise's } \\
\text { products, or comparing your enter- } \\
\text { prise unfavorably with other } \\
\text { enterprises? }\end{array}$} & $\begin{array}{l}\text { Bothers me } \\
\text { quite a bit }\end{array}$ & 55.2 & 56.8 & 66.4 & 61.2 \\
\hline \multicolumn{2}{|r|}{$\begin{array}{l}\text { 8. If you were to have a son, how } \\
\text { would you feel if someone sug- } \\
\text { gested that he work for the same } \\
\text { enterprise that you work for? } \\
\text { (If you are a woman, answer } \\
\text { for a daughter.) }\end{array}$} & Would approve & 29.8 & 41.2 & 54.3 & 61.9 \\
\hline \multicolumn{2}{|r|}{$\begin{array}{l}\text { 9. Are there things about working } \\
\text { here (people, policies, or con- } \\
\text { ditions) that discourage you } \\
\text { from working hard? }\end{array}$} & $\begin{array}{l}\text { No, most things } \\
\text { or practically } \\
\text { everything en- } \\
\text { courages me to } \\
\text { work hard }\end{array}$ & 37.9 & 37.2 & 44.9 & 49.7 \\
\hline \multirow{2}{*}{\multicolumn{2}{|c|}{$\begin{array}{l}\text { 10. Do people in your work group } \\
\text { encourage extra effort? } \\
\text { Average percentage }\end{array}$}} & $\begin{array}{l}\text { Considerably or } \\
\text { very encouraging }\end{array}$ & 42.8 & 37.8 & 49.1 & 51.0 \\
\hline & & & 40.0 & 47.2 & 51.9 & 57.1 \\
\hline
\end{tabular}


Table 3. It seems reasonable to assume at least that council and non-council members were not expressing a simple halo or response set in their reactions to these items. This assumption is further supported by the lack of consistent differences between noncouncil members and council members on questions about perceptions of control, communication, and decision making in the enterprises; questions referring to conditions external to the respondents, not the respondents themselves.

\section{Control}

Figures 1 and 2 show the distributions of actual and ideal control, based on the aver- aged judgments of all respondents in the four plants. The self-management hierarchy and the conventional chain of command in Yugoslav organizations are joined by the managers, who belong to both. For simplicity, data concerning both hierarchies are included in a single figure. The data in Figure 1 , describing the actual distribution of control, were obtained through the following question: How much influence do the following groups have on what happens in this firm? Responses were checked on a four-point scale from very great to very little. The groups are indicated along the horizontal axis of the figure. The data in Figure 2 describing the ideal distribution of

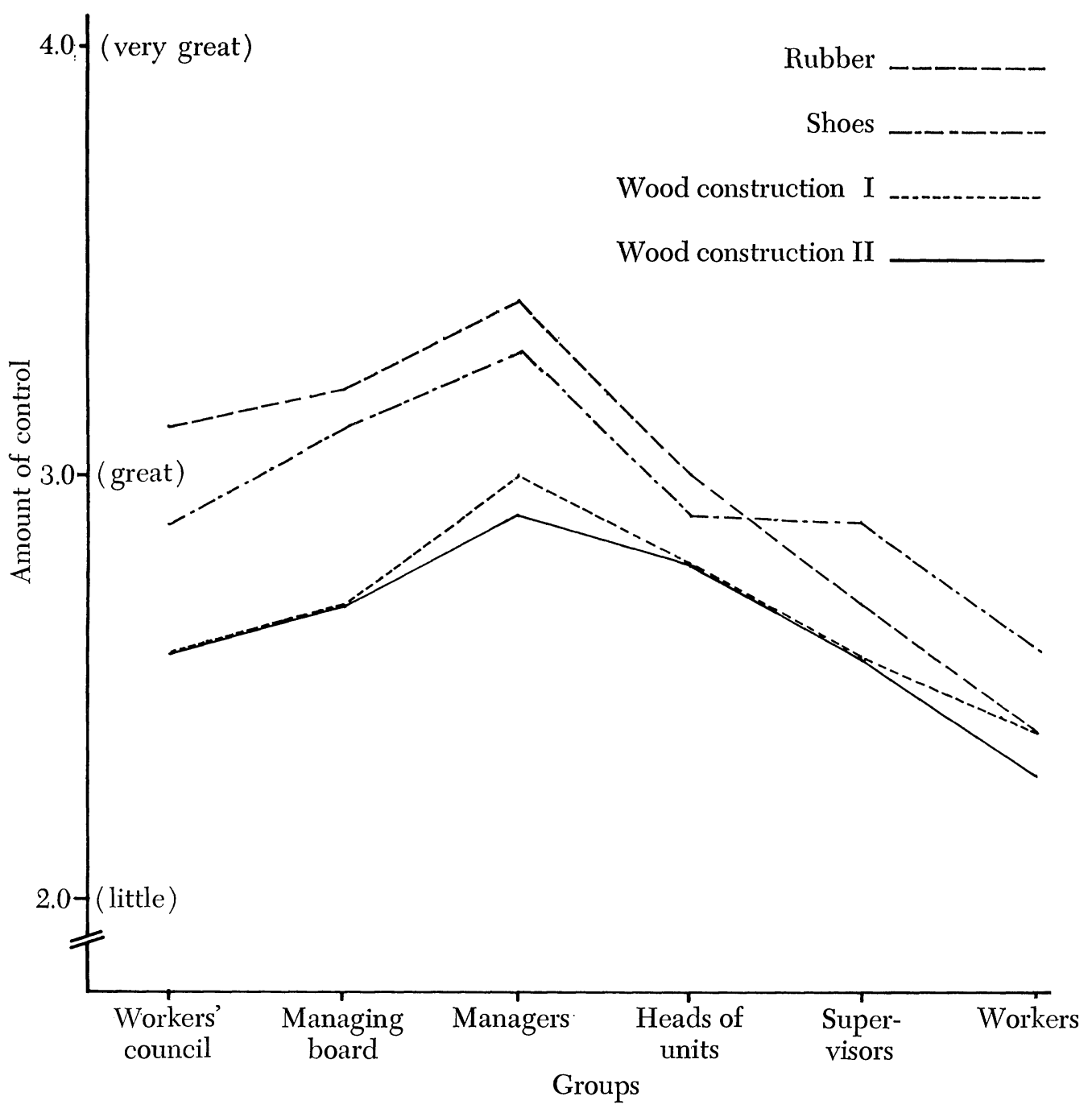

Figure 1. Curves of actual distribution of CONtrol 
control were obtained through the following question: How much influence should the following groups have on what happens in the firm?

The question on the actual distribution of control is a difficult one, and about 20 percent of the respondents did not answer. Therefore each curve of Figure 1 is based on the responses of approximately 120 persons, while each of those in Figure 2 is based on the responses of about 140 persons.

First, the general shape of the curves in the four plants is very similar to that found in earlier studies (Kavcic, 1968; Rus, 1964; Zupanov, 1964; Zupanov and Tannenbaum, 1968). Managers were judged to be the most influential group in their plants and workers the least influential. The workers' council was judged to have intermediate influence, despite its formal and ideologically sanctioned supremacy. Respondents did not seem to be offering simple, politically approved answers in response to the questions, but appeared to have applied themselves

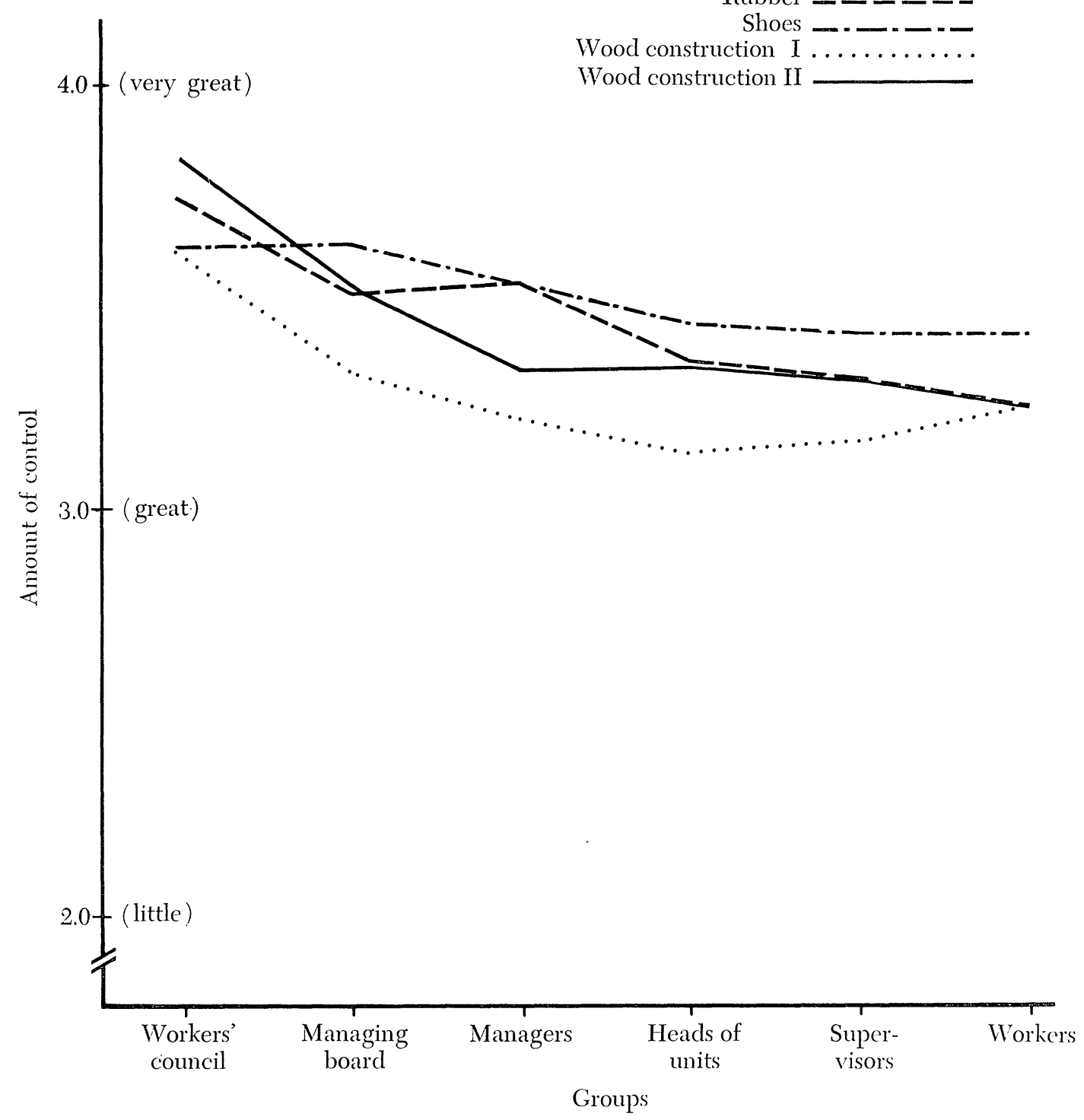

Figure 2. CuRves of IDEAL Distribution of CONTROL 
thoughtfully to the questions and attempted to provide an objective description of the control pattern in their plants. The similarity of these results to those found in other studies in Yugoslavia gives further support to these data and suggests some generality about the distribution of control in Yugoslav industrial plants.

Second, although the differences between some of the plants were not very great, Figure 1 shows a perfect rank-order correlation between the total amount of control in the plants, as indicated by the average heights of the curves, and overall effectiveness, as measured by the judgments of the 17 expert observers. This correlation is of course subject to various interpretations, given the small number of cases and the lack of controls in the design; but it is noteworthy that the results fit so well the hypothesized relationship for which empirical evidence has been found in some American organizations (Tannenbaum, 1968). A recent study in Yugoslavia by Mozina et al. (1970) adds further evidence for this hypothesis.

Third, the respondents discriminated well between actual and ideal control. The ideal curves are in all cases relatively flat, and the workers' council is chosen in all plants as that group for which the greatest amount of influence is desirable. The largest discrepancies between ideal and actual control occur for the workers and for the workers' council, the smallest discrepancies, for managers. These discrepancies correspond to the results of earlier studies in Yugoslavia (Rus, 1964; Zupanov, 1964; Zupanov and Tannenbaum, 1968).

Because the actual and ideal questions are so similar in format, one might expect them to be especially sensitive to response sets or halo-type responses. However, the ideal curves, unlike the actual curves, did not correlate with the effectiveness ratings, so that the data provide a second form of discrimination. Furthermore, the discrepancies between the actual and ideal curves did correlate $(-1.00)$ with effectiveness. These discrepancies, measured by summing within each organization the differences between the ideal and actual amount of control for each hierarchical level were 4.6, 3.5, 3.3, and 2.8 for the wood products II, I, shoes, and rubber plants respectively. Studies of such discrepancies and effectiveness in American plants were described by Smith and Tannenbaum (1963).

Fourth, these results, like the results of other industrial studies using the control graph, do not support the power-equalization hypothesis (Smith and Tannenbaum, 1963; Tannenbaum, 1968). This hypothesis, considered by some authors (Strauss, 1963; Leavitt, 1965) to be central to the human relations orientation, identifies participation with reduction of the differences in power between ranks in a hierarchy and predicts that such reduction of differences in power will have favorable effects on the motivation of members and their performance in the organization. The wood products plants, the least effective of the organizations studied, seemed to have the most equalized distribution of power; yet the workers and workers' councils in these power-equalized plants were not more influential than their counterparts in the other plants. Since the total amount of power may vary among plants, power equalization may very well reflect low power for all groups.

\section{Participativeness}

Figure 3 presents the results obtained in response to 8 questions adapted from an index developed by Likert (1967) to measure participativeness in organizations. Likert's scheme implies a continuum of organizations from exploitative authoritative to participative. Although the participative response is placed on the extreme right for all of the items shown in the figure, the directions of the scales were varied in the questionnaire so that a high score on some items implies a low value on participativeness. A ranking of the organizations on this measure of participativeness corresponds directly to the rankings of the organizations on the total amount of control and effectiveness measures, as predicted.

\section{Motivation, Involvement, and Identification}

Table 4 presents the results of 10 questions designed to measure motivation, involvement, and identification. The five-point 
scales used in these questions were varied in the questionnaire so that the favorable end was sometimes scored 1 and sometimes 5 . The distribution of responses of all re-

Questions

Exploitiveauthoritative 1

spondents in all plants for each question were dichotomized as close to the median as possible and the percentage of respondents falling on the favorable side of the

Benevolentauthoritative 2

$\begin{array}{cc}\text { Consultative } & \text { Participative } \\ 3 & 4\end{array}$

Does your superior behave so that you feel free to discuss important things about your job with him?

Does your superior in solving job problems try to get your opinions and suggestions and make constructive use of them?

Are the important decision makers in the enterprise aware of problems, particularly within the working units of the organization?

Do workers collaborate in decisions related to their work?

How do workers react to what they are told by their superiors?

What do workers tell their superiors?

What are the attitudes of the enterprise members toward the enterprise?

Are superiors concerned about the success of the enterprise?

(I do not feel at all free ...)

(I feel completely free ...)

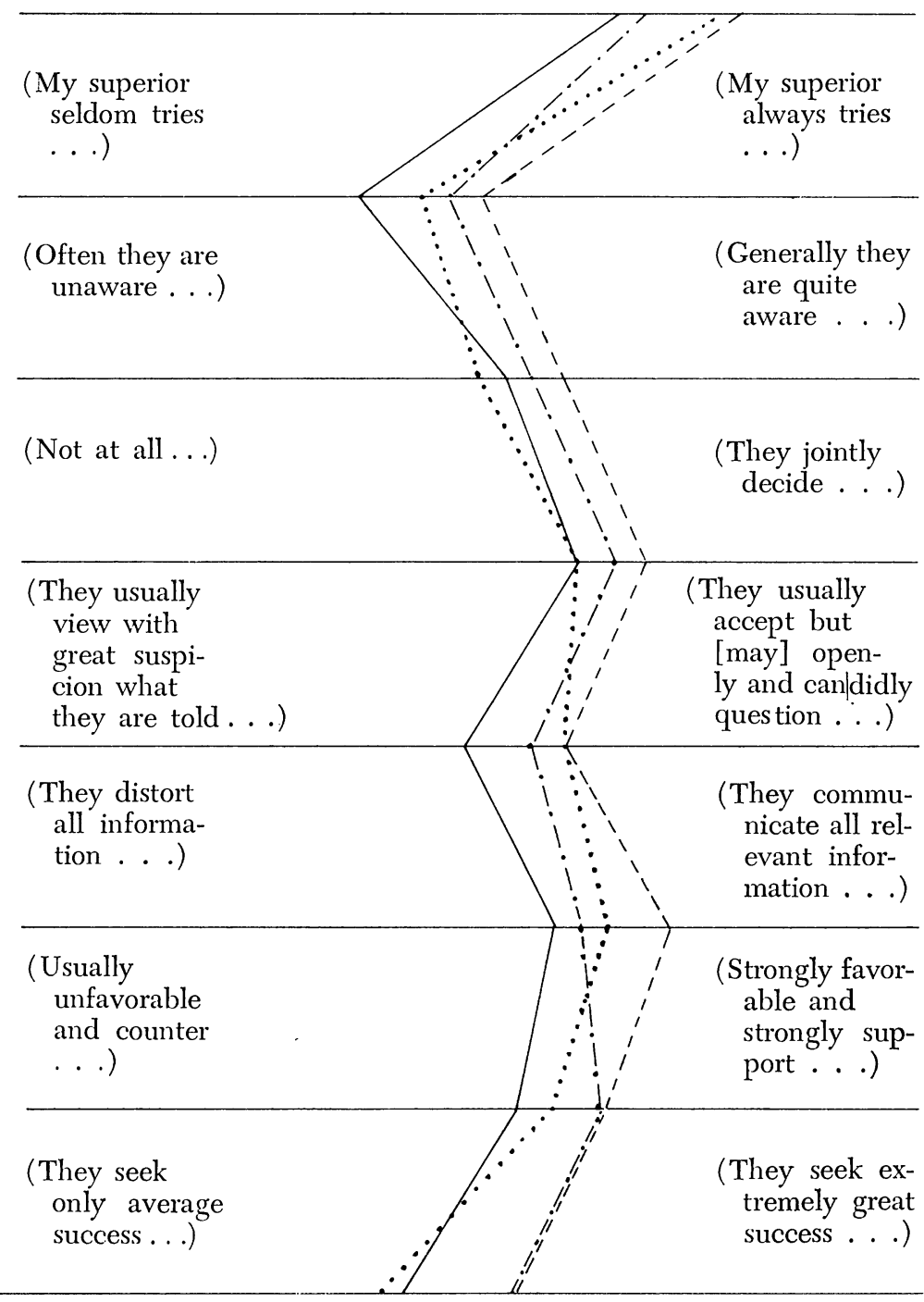


dichotomy in each plant is shown in the table. Although all of the questions do not show the expected correlations, the average percentages show the wood products II plant to be characterized by the lowest level of motivation, involvement, and indentification, while the rubber plant is characterized by the highest.

Questions 6 and 8 appear to offer particularly clear distinctions among the plants, consistent with the original hypothesis, but neither of these questions, intended to reflect identification with the plant, was found to discriminate consistently between council and non-council members. On the other hand, questions $3,4,5$, and 7, which discriminated best between council and non-council members, as shown in Table 3, were among the least discriminating between plants.

Since the main variables, with the exception of effectiveness, were measured through the judgments of organization members, the data were analyzed to determine whether the observed correlations represented relationships among individual responses-that is, individual effects-or correlations among characteristics of the organizations-structural or group compositional effects (Blau, 1957, 1960; Davis et al., 1961; Tannenbaum and Bachman, 1964). The results of the analysis suggested both structural and individual effects, and were consistent in their implications with the findings of Bachman et al. (1966) and Tannenbaum and Smith
(1964). These authors found in their results a distinction between subjective dependent variables, such as involvement and identification; and behavioristic variables, such as activity level or performance of members. Analyses by these authors involving behavioristic dependent variables suggested only structural effects, while analyses with subjective variables, as in the present study, suggested both structural and individual effects.

\section{Influence of Workers' Council}

The workers' councils in the plants studied exercised substantial influence, according to the respondents, but were not as influential as the members wished them to be, nor as influential as ideology required. Furthermore, the councils did not provide the workers with the sense of control that councils were designed to provide. Table 5 represents data for all plants in answer to the question: In your opinion, what kind of a job is the workers' council in this enterprise doing? Although members of the organizations rated their councils as having great influence, they did not rate them as being very effective, as Table 5 shows. Council members did not differ very much from noncouncil members in their appraisal of their councils; and the evaluations by both were preponderantly fair to poor. This appraisal no doubt reflects the judgment by organization members that the councils do not exer-

TABle 5. RAtings, In Percent, OF COUNCIL EFFECTIVENESS

\begin{tabular}{|c|c|c|c|c|c|c|}
\hline \multirow[b]{2}{*}{ Industry } & \multirow[b]{2}{*}{$N$} & \multicolumn{5}{|c|}{ Council effectiveness } \\
\hline & & Excellent & Good & Fair & Poor & Very poor \\
\hline \multicolumn{7}{|l|}{ Wood products II } \\
\hline Council members & 34 & 11.8 & 17.6 & 41.2 & 17.6 & 11.8 \\
\hline Non-council members & 111 & 2.7 & 11.7 & 57.6 & 14.4 & 13.6 \\
\hline \multicolumn{7}{|l|}{ Wood products $I$} \\
\hline Council members & 31 & 3.2 & 6.4 & 45.2 & 38.7 & 6.5 \\
\hline Non-council members & 117 & 3.4 & 6.8 & 50.4 & 28.2 & 11.2 \\
\hline \multicolumn{7}{|l|}{ Shoes } \\
\hline Council members & 31 & 6.4 & 19.3 & 51.4 & 12.9 & - \\
\hline Non-council members & 118 & 6.8 & 10.2 & 64.4 & 16.1 & 2.5 \\
\hline \multicolumn{7}{|l|}{ Rubber } \\
\hline Council members & 26 & - & 26.9 & 57.7 & 11.6 & 3.8 \\
\hline Non-council members & 121 & 4.1 & 13.2 & 63.6 & 14.9 & 4.2 \\
\hline All plants & 589 & 4.6 & 11.9 & 57.4 & 18.8 & 7.3 \\
\hline
\end{tabular}


cise the influence they should, but there are other explanations of this appraisal.

First, the possible social-psychological effects of indirect or representational participation are limited. Many of the daily events for workers, including the frustrating aspects of technology and bureaucratic administration, are not very much changed by the fact that some members of the organization participate in monthly council meetings. Workers may be too far removed from the actual deliberations of the council to develop the sense of involvement that participation in such deliberations might engender. The workers' daily routine and relationships with supervisors and co-workers may continue unchanged, even though the council makes decisions that affect organization policy.

Second, many elected representatives may not be very influential in the council, as Table 6 indicates; consequently the constitu-

TABle 6. Amount of CONTROL EXerCised BY GROUPS WITHIN WORKERS' COUNCIL

\begin{tabular}{lc}
\hline Group & Amount of control \\
\hline Managers & 3.0 \\
Staff & 2.9 \\
Heads of economic units & 2.8 \\
Supervisors & 2.5 \\
Highly skilled and skilled workers & 2.4 \\
Semiskilled and unskilled workers & 2.1 \\
\multicolumn{1}{c}{ Scale: $\quad 4$ = very great } & \\
& \\
& \\
& 2 = great \\
& 1 little very little \\
\hline
\end{tabular}

ents of these members cannot feel that as constituents they have influence in the council. Table 6 represents data for all plants in response to the following question: How much influence do the following groups have on what goes on within the workers' council? Council members did not differ systematically from ordinary members in their responses to this question. Managerial and staff members exercise great influence within the council while the less-skilled workers exercise little. The less-skilled workers in the council, because of their small influence, are not really able to represent their co-workers and therefore cannot provide them with a sense of control, direct or indirect.

Third, members of the council differ from non-council members in motivation, involvement, and identification, as shown in Table 3 , but the extent of the differences between the two groups is not as great as expected, suggesting that the council may not affect even its own members as much as we had assumed.

\section{DISCUSSION}

A study of four organizations hardly provides the basis for significant generalizations, and the special limitations in the design of this research leave the data open to a number of interpretations. It seems reasonable to assert, however, that the organizations studied do differ from one another with respect to participativeness, levels of control, and the motivation, involvement, and identification of members as measured through the questionnaire. Also, the independently obtained measures of organizational effectiveness correspond in expected ways to variations in the above characteristics. The finding that participativeness in the council does not bring about the desired effects of participation throughout the organization supports the tentative conclusion of Lammers (1967: 215) that "effective direct participation in industrial organization bears little or no relationship to effective forms of indirect participation." Thus, within a Yugoslav context, some indication of correlations like those found elsewhere is seen, although these correlations are far from being explained with confidence. It is impossible from this research to determine cause from effect. Furthermore, other differences among the plants might underlie the variations observed. For example, the organizations differed in size, type of product, and in the age, sex, and educational level of the members. Educational level might very well affect the levels of participativeness and control within the plants, since participation requires the skills and understanding that education may provide. It would not be surprising therefore to find that organizations that have more participation and are more effective include more highly educated workers. It is perhaps surprising that organizations with greater participation and those characterized by greater member involvement, motivation, and identification are the larger rather than 
the smaller ones. Nonetheless, the major relationships expected were supported by the data.

This study provides some clues about the possible character of control, participation, and effectiveness in Yugoslav organizations. The very tentative conclusions made here do not imply that workers' councils are without value. They do suggest, however, that the council by itself may not have the farreaching effects that many advocates believe. The data indicate that an influential council may be part of a larger organizational system of high influence characterizing an organization that is effective, and that an influential council, like influential managers, supervisors, or workers can contribute to the total influence and to the effectiveness of the organization. The council must be influential if its members are to be influential. Influential council members in turn provide one means through which non-council members can exercise influence, for the non-council member is not likely to exercise influence through his council representative unless that representative is influential. Nor is the non-council member likely to be influenced very much by his representative, unless the latter is influential in the council. And unless the control process involves some mutuality, it is not likely to have the integrative effects that participation is supposed to achieve. Thus increased control in the organization is tied to increased control in the council, and this depends on a network of interaction and mutual influence that pervades the total organization. But the effective organization with high participation is not necessarily a power-equalized organization. High control by a workers' council or by workers need not be achieved at the expense of managerial control; on the contrary, low control by managers may imply low control for all.

Bogdan Kavcic is a research director of the center for public opinion research of the trade union council of the Slovenian Republic; Veliko Rus is a professor in the school of sociology, political science and journalism at the University of Ljubljana; and Arnold S. Tannenbaum is the program director of the institute for social research at the University of Michigan.

\section{REFERENCES}

Adizes, Ichak

1968 The Effect of Decentralization on Organizational Behavior. Doctoral dissertation, University of California at Los Angeles.

Bachman, Jerald G., Clagett G. Smith, and Jonathan A. Slesinger

1966 "Control, performance, and satisfaction: an analysis of structural and individual effects." Journal of Personality and Social Psychology, 4: 127-136.

Blau, Peter

1957 "Formal organization: dimensions of analysis." American Journal of Sociology, 63: 58-69.

1960 "Structural effects." American Sociological Review, 25: 178-193.

Bowers, David G.

1969 Survey of Organizations. Ann Arbor: Institute for Social Research, University of Michigan.

Coch, Lester, and John French, Jr.

1948 "Overcoming resistance to change." Human Relations, 1: 512-533.

Dahrendorf, Ralf

1955 Mitbestimmungsproblem in der Deutschen Sozial Forchung: Eine Kritic. Munich: Piper.

Davis, James A., Joe L. Spaeth, and Carolyn Huson

1961 "A technique for analyzing the effects of group composition." American Sociological Review, 26: 215-225.

Deleon, Aser

195633 Questions, 38 Answers on Workers' Self-Government in Yugoslavia. Belgrade: Publicity Enterprise.

Dunlop, John T.

1959 Industrial Relations Systems. New York: Holt.

Emery, Frederick, and Einar Thorsrud

1965 Industrial Democracy. London: Tavistock.

Friedmann, Georges

1955 Industrial Society. Glencoe, Ill.: Free Press.

Katz, Daniel, and Robert Kahn

1966 The Social Psychology of Organizations. New York: John Wiley.

Kavčič, Bogdan

1968 Distribucija Vpliv V Podjetjih Industrije in Rudarstva V. Sloveniji, Ljubljana: Center za Raziskovanje Jaunega Mnenja Pri. Working paper, Zveza sindikatov Jugoslavije Republiski svet za Slovenijo, Ljubljana. 
Kolaja, Jiri

1965 Workers' Councils. London: Tavistock.

Kralj, Janko

1969 New Management Systems in the Planned Economy-from the point of View of Yugoslav Workers' Self-Administration in Conditions of Planned Mixed Economy. Working paper, International Management Association of Japan, Tokyo.

Lammers, C. J.

1967 "Power and participation in decisionmaking in formal organizations." American Journal of Sociology, 73: 201-216.

Leavitt, Harold J.

1965 "Applied organizational change in industry: structural, technological and humanistic approaches." In James G. March (ed.), Handbook of Organizations: 1134-1170. Chicago: Rand McNally.

Likert, Rensis

1961 New Patterns of Management. New York: McGraw-Hill.

1967 The Human Organization. New York: McGraw-Hill.

Mandić, Oleg

1958 "Yugoslavia." In Arnold M. Rose (ed.), The Institutions of Advanced Societies: 274-329. Minneapolis: University of Minnesota Press.

Mozina, Stane, Janez Jerovsek, Arnold S. Tannenbaum, and Rensis Likert

1970 "Testing a management style." European Business, 27: 60-68.

Patchen, Martin

1963 Questionnaire Measures of Employee Reactions to Jobs. Ann Arbor: Institute for Social Research, University of Michigan.

Rus, Veljko

1964 Status Vodstvenega Kadra v Pogojih Samoupravljanja. Kranj: Zovad as organizacijo dela V. Kranju.

Siber, Ivan, Kljaic Slavko, Miljenka Magdic, Branko Sverko
1966 "Percepcija distribucije utjecaje u radnoj organizaciji." Politicka Misau, 4.

Smith, Clagett, and Arnold S. Tannenbaum

1963 "Organization control structure: a comparative analysis." Human Relations, 16: 299-316.

Strauss, George

1963 "Some notes on power-equalization." In Harold J. Leavitt (ed.), The Social Science of Organizations: 41-84. Englewood Cliffs, N.J.: Prentice-Hall.

Sturmthal, Adolf

1964 Workers' Councils. Cambridge: Harvard University Press.

Tannenbaum, Arnold S.

1966 Social Psychology of the Work Organization. Belmont, Calif.: Wadsworth.

1968 Control in Organizations. New York: McGraw-Hill.

Tannenbaum, Arnold S., and Jerald Bachman

1964 "Structural versus individual effects." American Journal of Sociology, 69: 585-595.

Tannenbaum, Arnold S., and Clagett Smith

1964 "Effects of member influence in an organization: phenomenology versus organization structure." Journal of Abnormal and Social Psychology, 69: 401-410.

Yuchtman, Ephraim, and Stanley E. Seashore

1967 "A system resource approach to organizational effectiveness." American Sociological Review, 12: 891-903.

Zupanov, Josip

1964 Grafikon utjecaja kao analiticko crude za izucavanje strukturalne promjene socijalne organizacije poduzeca. Doctoral dissertation, Ekonomski Institut, Zagreb.

Zupanov, Josip, and Arnold S. Tannenbaum

1968 "The distribution of control in some Yugoslav industrial organizations as perceived by members." In Arnold S. Tannenbaum (ed.), Control in Organizations: 91-109. New York: McGraw-Hill. 